\title{
The value of lunch provided by schools in relation to the total diet of teenagers
}

\author{
C. E. Handford ${ }^{1}$, C. J. Prynne ${ }^{1}$, V. Dunn ${ }^{2}$, D. Bamber ${ }^{2}$, I. Goodyer ${ }^{2}$ and A. M. Stephen ${ }^{1}$ \\ ${ }^{1}$ MRC Human Nutrition Research, Elsie Widdowson Laboratory, Cambridge CB1 9NL, UK and ${ }^{2}$ Department of Psychiatry, \\ University of Cambridge CB2 $8 A H, U K$
}

In England approximately $3 \times 10^{6}$ school meals are served each day. The National Diet and Nutrition Survey (NDNS) of 4-18 year olds in 1997 reported that these meals contribute between one-quarter and one-third of the daily intake of energy, fat, dietary fibre, Fe, Ca, vitamin $\mathrm{C}$ and folate ${ }^{(1)}$. The report found that the typical diet of UK children was not balanced, with many children consuming high levels of saturated fat, $\mathrm{Na}$ and sugars and low amounts of $\mathrm{Zn}, \mathrm{Ca}, \mathrm{Fe}$, vitamin A and NSP. Evidence from a recent survey also suggests that school meals are increasingly catering for children's liking of high-fat foods, as $48 \%$ of schoolchildren surveyed chose foods such as chips or burgers at lunchtime ${ }^{(2)}$. This finding has resulted in an increased concern about the quality of school lunches, which have been the subject of much criticism in the media. In 2005 the government responded to these concerns by introducing new food- and nutrient-based standards for school meals, which focused on changing the eating habits of young individual ${ }^{(3)}$.

Information was collected on the diets of 933 teenagers, aged 14-15 years, across nineteen schools in Cambridgeshire during 2005-7. All food and drinks consumed over a $4 \mathrm{~d}$ period, including two weekdays and two weekend days, were recorded in a food diary. The diets were coded and analysed using the in-house food composition database that is based on McCance and Widdowson's Composition of Foods ${ }^{(4)}$. Results presented are for 393 pupils who ate food provided by schools, either on one or both of the school days recorded; a total of 612 school lunches.

\begin{tabular}{|c|c|c|c|c|c|c|c|c|c|c|c|}
\hline \multirow[b]{3}{*}{ Nutrient } & \multicolumn{5}{|c|}{ Boys $(n 150)$} & \multicolumn{5}{|c|}{ Girls (n 243) } & \multirow[b]{3}{*}{ CWT* } \\
\hline & \multicolumn{2}{|c|}{ Daily intake } & \multicolumn{2}{|c|}{ Lunch intake } & \multirow{2}{*}{$\begin{array}{c}\text { Lunch } \\
\text { (\% daily) }\end{array}$} & \multicolumn{2}{|c|}{ Daily intake } & \multicolumn{2}{|c|}{ Lunch intake } & \multirow{2}{*}{$\begin{array}{c}\text { Lunch } \\
\text { (\% daily) }\end{array}$} & \\
\hline & $\overline{\text { Mean }}$ & SD & Mean & $\mathrm{SD}$ & & Mean & $\mathrm{SD}$ & Mean & $\mathrm{SD}$ & & \\
\hline Energy (MJ) & 8.8 & 2.7 & 2.5 & 1.3 & 29 & 7.2 & 2.7 & 1.9 & 1.1 & 28 & $3.4 / 2.6$ \\
\hline Fat $(\mathrm{g})$ & 83 & 33 & 26 & 18 & 31 & 68 & 31 & 19 & 13 & 29 & \\
\hline Fat ( $\%$ energy) & 35 & 7.5 & 36 & 14.4 & & 35 & 7.9 & 35 & 15 & & $\leq 35$ \\
\hline $\mathrm{Ca}(\mathrm{mg})$ & 979 & 489 & 242 & 212 & 25 & 861 & 1360 & 201 & 155 & 27 & $400 / 320$ \\
\hline $\mathrm{Fe}(\mathrm{mg})$ & 11.6 & 4.8 & 2.7 & 1.7 & 24 & 9.2 & 4.4 & 2.1 & 1.3 & 25 & $4.5 / 5.9$ \\
\hline Vitamin C (mg) & 114 & 108 & 24 & 44 & 22 & 85 & 76 & 20 & 37 & 23 & 16 \\
\hline NSP (g) & 12.8 & 5.4 & 3.4 & 2.5 & 27 & 11.5 & 6 & 3.2 & 2.2 & 31 & 5.4 \\
\hline Folate $(\mu \mathrm{g})$ & 248 & 110 & 56 & 42 & 24 & 196 & 95 & 49 & 43 & 26 & 80 \\
\hline
\end{tabular}

CWT, Caroline Walker Trust. *School lunch intakes as recommended by the $\mathrm{CWT}^{(4)}$

The percentage contribution from school lunches to total energy and nutrients was very similar to that reported for secondary school pupils in the 1997 NDNS Survey of Young People ${ }^{(1)}$. Also similar was the finding that intakes of energy, NSP and many micronutrients fell below the Caroline Walker Trust (CWT) recommendations for school meals, which were adopted as the government standards ${ }^{(5)}$. Girls in particular were obtaining less than half the recommended levels of Fe, while Ca intakes were very low for both genders. While not meeting the CWT standards, Cambridge boys were obtaining more of their daily requirement of Fe, folate and vitamin $\mathrm{C}$ and girls more of their Ca from school lunches compared with secondary school pupils in 1997. Vitamin C intakes from school lunches exceeded the recommendation of $\geq 40 \%$ of the reference nutrient intake. In this sample many subjects ate fruit from the school canteens even when they did not eat a full school meal.

These results are evidence that between 1997 and 2006 there has been very little improvement in the quality of meals provided by schools. Although the government guidelines were published in 2005 the regulations for nutrient-based standards were not due to come into force until September 2009 in secondary schools so at the time these Cambridgeshire data were collected the new recommendations were not statuary. As less than half the pupils in this sample ate school lunch and of those some just took a piece of fruit and a drink, it is not certain that improvements in school meals will result in a marked difference to the total diet of these teenagers.

1. Nelson M, Lowes K \& Hwang V (2007) Public Health Nutr 10, 652-662.

2. Noorani S (2005) Nutr Bull 30, 278-281.

3. School Meals Review Panel (2005) Turning the tables: transforming school food. http://www.dcsf.gov.uk/consultations/downloadableDocs/ Government\%20response\%20FINAL\%20VERSION.pdf

4. Food Standards Agency. (2002). McCance and Widdowson's The Composition of Foods, Sixth summary edition. Cambridge: Royal Society of Chemistry.

5. Caroline Walker Trust (2005) Nutrient-based Standards for School Food. London: National Heart Forum. 